\title{
In vitro Antifungal Activity of Some Plant Extracts against Seed-borne Pathogens
}

\author{
F. A. Abushaala ${ }^{1}$, A. R. Ben Ramadan ${ }^{1}$, M. A. S. Fahej ${ }^{2}$ \\ ${ }^{1-}$ Microbiology Department, Faculty of Science, Misurata University, Libya \\ ${ }^{2-}$ Biology Department, Faculty of Science, Elmergib University, El-khums, Libya.
}

\begin{abstract}
Chemical fungicides cause serious environmental problems. Plant metabolites and plant based pesticides considered to be better alternatives as they are known to have minimal environmental impact in contrast to synthetic pesticides. In this study some plant extracts in different concentrations were tested in vitro for their activity against some cucurbit seed-borne fungi. All tested plant extracts significantly reduced the growth of the tested damping-off pathogens at all tested concentrations. F. semitictum and F. solani were more sensitive to plant extracts treatment than the other tested pathogens, where R. raetam extracts with $15 \%$ and $10 \%$ concentrations as mean were more effective to tested damping-off pathogens, whereas $R$. raetam 5\% concentration and P. dactylifera 15\% concentration were similarly efficient in suppression $(30.0$ and $30.2 \mathrm{~mm}$, respectively). C. trifurcatum gave lowest effect, whereas $P$. dactylifera $5 \%$ and $C$. trifurcatum $15 \%$ gave the equal values $(27.2 \%)$. The highest inhibitory zone values were obtained by the plant extract $R$. raetam (32.53 mm as a mean values). F. solani, $F$. semitictum and $F$. moniliforme were more sensitive with the highest inhibitory zone values due to plant extract treatments (37.0, 36.0 and $36.0 \mathrm{~mm}$, respectively).
\end{abstract}

Keywords: Damping-off pathogens, Plant extract, Cucurbit seed-borne fungi, Antifungal activity.

\section{Introduction}

Cucurbits are important vegetable crops that daily consumed world over. The family cucurbitaceae, includes cucumber (Cucumis sativus), squash (Cucurbita pepo), watermelon (Citrullus lanatus), cantaloupe (Cucumis melo var. cantaloupensis), snak cucumber (Cucumis melo var. flexuosus), sweetmelon (Cucumis melo) and pumpkin (Cucurbita sp.). Serious soil-borne and seed-borne pathogens, i.e. Pythium debaryanum, $P$. ultimum, P. dissotocum, P. oligandrum, P. violae, P. aphanedermatum, Macrophomina phaseolina, Rhizoctonia solani, Fusarium solani, F. semitectum, Aphanomyces euteiches, Sclerotinia sclerotiorum and many species of Verticillium and Cladosporium., can cause damping-off and root rot diseases, resulting in great economic losses in crop yield and quality.

The use of fungicides for control of these pathogens has met moderate success and their future use is in question due to increased regulatory restrictions. So, the modern approach in plant disease control is directed toward minimizing the fungicidal use to decrease environmental pollution and finding alternatives to chemical fungicides. Hence, in recent time application of plant extracts as well as plant metabolites for plant disease management has become important viable component of Integrated Pest Management, as plant metabolites are eco-friendly where botanicals place an important role (Sahayaraj et al., 2009). Several investigation studies have been conducted in order to screening different plants for their antifungal properties (Stephan et al., 2005 and Satish et al., 2010) and biochemical compounds that these plants have. Studies revealed a highly significant antifungal activity of some water extracts or essential oils of plants. Since some plants are already known to possess several biological activities (Amin et al., 2009 and Belabid et al., 2010).

\section{Plant extracts:}

The antimicrobial activity of secondary metabolites and lectins, compounds usually associated to defense mechanisms of plants. Secondary metabolites are separated into nitrogen compounds (alkaloids, nonprotein amino acids, amines, alcamides, cyanogenic glycosides and glucosinolates) and nonnitrogen compounds (monoterpenes, diterpenes, triterpenes, tetraterpenes, sesquiterpenes, saponins, flavonoids, steroids and coumarins). Lectins are carbohydrate-binding proteins and their biological properties include cell-cell interactions. This chapter reports solvent organic extracts (mixture of secondary metabolites), isolated secondary metabolites and lectins from plants with antimicrobial activity against Gram-negative and Gram-positive bacteria as well as antifungal activity towards human and plant pathogens. Effects of plant secondary metabolites and lectins on deleterious human and plant microorganisms indicate their perspectives of antimicrobial uses (Paiva et al., 2010). Solvent organic extracts contain a mixture of secondary metabolites including alkaloids, flavonoids, terpenoids and other phenolic compounds; these molecules are associated to defense mechanisms of plants by their repellent or attractive properties, protection against biotic and abiotic stresses and maintenance of structural integrity of plants (Tepe et al., 2005). 


\subsection{Retama raetam:}

Retama raetam (Forssk.) Webb \& Berthel. (Fabaceae alt. Leguminosae), commonly known as 'raetam' or 'broom bush', is a desert shrub native to several countries of North-Africa (e.g., Algeria, Egypt, Libya, Morocco and Tunisia), temperate Asia (e.g., Israel, Jordan, Lebanon, Palestine and Syria) and south-eastern Europe (e.g., Sicily in Italy) (GRIN Database, 2011). This plant has long been used as an abortifacient, a purgative and a vermifuge in the traditional medicine systems of the source countries (Dr. Duke's Phytochemical and Ethnobotanical Databases, 2011). Previous pharmacological studies on this plant have revealed its antibacterial, antifungal, antihypertensive, anti-oxidant, antiviral, diuretic and hypoglycemic properties and hepatoprotective, nephroprotective and cytotoxic effects (Hayet et al., 2008; Koriem et al., 2009; Algandaby et al., 2010 and Edrizi et al., 2010). In continuation of our phytochemical and pharmacological studies on the Libyan medicinal plants (Auzi et al., 2008; Elouzi et al., 2008 and Geroushi et al., 2010).

\subsubsection{Phytochemical Screening:}

During the last decades, a huge number of chemical compounds have been isolated from the genus Retama, including flavonoids, alkaloids, saponins, lignans and others (Harborne, 1969 and Harborne et al., 1971). Abdel Halim et al., (1997) reported that, Retama species contain flavonoids and alkaloids. Phytochemical studies have shown that Retama species are very rich in flavonoids, tritepenoides, saponins, alkaloids, phytosterols, cellulose, hemicellulose and lignin (Moubasher, 1998; Kassem et al., 2000 and Cheriti et al., 2004). Djeddi et al., (2013) found that the isoflavones genistein, 6-hydroxygenistein, 3'-Omethylorobo, pratensein, biochanin A, the flavones 6-hydroxyapigenin and luteolin, the flavonol kaempferol, as well as the phenolic compound p-coumaric acid reduce significantly the pain at a concentration dose of $1 \mathrm{mg} / \mathrm{kg}$. Mobin et al., (2015) reported that, the phytochemical screening of the $R$. raetam extracts revealed the presence of alkaloids, phenols, flavonoids, terpenoids, tannins and carbohydrates. However, saponins were absent.

\subsubsection{Antifungal activity:}

Previous pharmacological studies on the plant have revealed its various medicinal properties: antibacterial, antifungal, antihypertensive, antioxidant, antiviral, diuretic, hypoglycaemic, hepatoprotective, nephroprotective and cytotoxic effects (Edziri et al., 2010). Hayet et al., (2007) showed the activity of Retama raetam was low against the different Candida spp., i.e. C. glabrata, C. albicans, C. parapsilosis and C. kreusei. Edziri et al., (2010) indicated that the antibacterial, antifungal and cytotoxic activities of two flavonoids isolated from $R$. raetam flowers. The compounds licoflavone $\mathrm{C}$ and derrone showed important antifungal activity. Strong antifungal activity against Candida species $(7.81 \mu \mathrm{g} / \mathrm{mL})$ was for example found with derrone. These two compounds may be interesting antimicrobial agents to be used against infectious diseases caused by many pathogens.

\subsection{Phoenix dactylifera:}

\subsubsection{Phytochemical Screening:}

Whole plant contains Carbohydrates, steroids, alkaloids, flavonoids, tannins and vitamins. Its phenolic profile shows that it contains cinnamic acids, falconoid glycosides and flavones. Dates contain nutrients as carbohydrates $(44-88 \%)$, dietary fibers $(6.4-11.5 \%)$, fats $(0.2-0.5 \%)$ and proteins $(2.3-5.6 \%)$. Dates contain fatty acids as palmitolieic acid, Oleic, linoleic and linolenic acid. In dates, 23 amino acids are found. Furthermore vitamin A, B1, B2 and nicotinic acid are also found in dates stated by Abdu, 2011. Several studies on antimicrobial activity of $P$. dactylifera have been reported (Vyawahare et al., 2009); however antifungal potential of date palm extracts have not been explored.

Fungi are very large and diverse group of organisms, which are responsible for causing large number of diseases to human beings, animals and plants (Mehrotra, 1993). Delphin et al., (2014) revealed the presence of seed ethanolic extracts of Phoenix dactylifera contains saponin, terpenoids, phenolic compounds and glycosides but none contains tannins, flavonoids, carotenoids, protein, carbohydrate and alkaloids. Chinelo et al., (2012) studied the aqueous extract of the fruits of Borassus aethiopum, Borassus flabellifer, Balanite aegyptiaca, Phoenix dactylifera and Tamarindus indica were tannins, saponins, phlobotannins, terpenoids, flavonoids, cardiac glycosides, glycosides, phenol, anthracene, free-anthraquinone, carotenoids, steroid, reducing compounds and alkaloids. All plant specimens seem to potential as a source of useful drugs.

\subsubsection{Antifungal activity:}

Bokhari and Perveen (2012) tested water, methanol and acetone extract of leaves and pits of Dates on seven pathogenic fungi $F$. oxysporum, Fusarium sp., F. solani, A. flavus, A. alternata, Alternaria sp. and Trichoderma sp. by agar well diffusion and agar dilution method against fungi. Methanol pits extract was highly effective against most of the tested fungi followed by methanol leaves extract, acetone pits and acetone leaves extract. The most sensitive fungus was A. alternata, its growth inhibition was maximum (51.6\%) by methanol 
pits extract of var. Barhee. 50\% inhibitory effect (IC50) of methanol pits extract of var. Barhee against $F$. oxysporum, F. solani, Fusarium sp., A. alternata and Alternaria sp. was found to be 6.7, 4.9, 3.4, 2.8 and 3.7 $\mathrm{mg} / \mathrm{ml}$, respectively. Water extracts of both varieties showed no effect on growth of tested fungi. Strong antifungal activity was seen with methanol pits and leaves extract against A. alternata. Poor to negligible antifungal activity was seen with all extracts against $A$. flavus. Order of activity according to zone of inhibition against almost all fungi is as follows: Methanolic pits extract $>$ Methanolic leaves extract $>$ Acetone pits extract $>$ Acetone leaves extract. Boulenouar et al., (2011) stated that dichloromethane extract of date fruit has also antifungal activity.

\subsection{Chrysantimum trifurcatum:}

\subsubsection{Phytochemical Screening:}

Ukiya et al. (2002) reported that the phytochemical profile of Chrysanthemum species has shown the presence of terpenoids. Ahlem et al. (2008) indicated that the most plentiful constituent of flowers' head, leaves and stems essential oils from Tunisian $C$. trifurcatum was limonene. But in the roots oil, $\alpha$-Calacorene was the predominant compound. Although, the essential oils from all parts of $C$. trifurcatum were rich in terpenoid components. Lin and Harnyl (2010) reported that the phytochemical profile of Chrysanthemum species has shown the presence of flavonoids and phenolic compounds. Zhang et al. (2012) showed that the ethyl acetate extract of $C$. indicum contains terpenes and flavonoids mainly. Besides, the content of flavonoids in ethanol extract is the highest by comparison with different extracts. Umadevi and Sujatha (2013) reported that the methanolic and acetone crude extracts of $C$. trifurcatum leaves from India contained tannins, flavonoids, terpenoids, alkaloids, saponins, cardiac glycosides, reducing sugars and triterpenoids. Ahlem et al. (2014) reported that, tannins, alkaloids and flavonoids were detected in the methanolic extracts of all parts of $C$. trifurcatum. But, all petroleum ether extracts do not contain tannins, flavonoids and alkaloids. Among, all ethyl acetate extracts showed the presence of tannins. Based on this preliminary phytochemical analysis, the methanol extract of $C$. trifurcatum showed the presence of important bioactive compounds, namely tannins, flavonoids and alkaloids. Other researches, suggested that, flavonoids, triterpenes, vitamin, and polysaccharides were the main active ingredient of $C$. morifolium (Lin and Harnyl, 2010 and Xiaoyan et al. 2011). Recently, it has been signaled that $C$. morifolium was rich in flavonoids, glycosides and caffeoylquinic acids (Tao et al., 2013). In addition, $C$. coronarium and $C$. segetum were rich in flavonoids (Valant-Vetschera et al., 2003).

\subsubsection{Antifungal activity:}

Bahraminejad et al., (2013) showed that methanolic crude extracts of 32 plant species inclouded Chrysanthemum sp. belonging to 21 families collected from the west of Iran were screened for antifungal activity against three phytopathogenic fungi, Phytophthora drechsleri, Pythium aphanidermatum and Rhizoctonia solani. Bioassay of the extracts was conducted by agar diffusion method on agar plate cultures with five replications. Twenty-seven of the $32(85 \%)$ plant species tested, showed inhibitory activity against at least one of the fungi. Seventeen $(53 \%)$, thirteen $(41 \%)$ and seventeen $(53 \%)$ tested plant species showed inhibitory activity against mycelia growth of $P$. drechsleri, $P$. aphanidermatum and $R$. solani, respectively. Ahlem et al. (2014) reported that the most active $C$. trifurcatum extracts tested against bacterial strains, contained tannins, flavonoids and alkaloids. They can be toxic to bacteria, yeasts and filamentous fungi (Scalbert, 1991). Their mode of antimicrobial action may be related to their ability to inactivate microbial adhesions, enzymes, cell envelope transport proteins and they also complex with polysaccharide (Ya et al. 1988). Furthermore, flavonoids were known to be synthesized by plants in response to microbial infection (Dixon et al. 1983). Ahlem et al. (2014) showed that, essential oils and organic extracts were tested for antibacterial activities against eight Gram-positive and Gram-negative strains, using a microdilution method.

Antifungal activity of $R$. raetam and $C$. trifurcatum has not been reported earlier. We carried out this study to investigate the antifungal, activities of the ethanolic extracts of tested plant parts. Therefore, the objective of this work is controlling the isolated damping-off and root rot pathogens, using some plant extracts in vitro.

2. Disease Control:

\section{Materials and Methods}

\subsection{Plant Extract:}

\subsubsection{Preparation of Plant Crude Extracts:}

The plants namely, Retama raetam (flowers, Stems \& fruits) and Phoenix dactylifera (seeds) were collected from Misurata region in north Libya, while Chrysanthemum trifurcatum (mixed of leaves, stems and roots) was collected from Alojaylate and Mizda in west and south Libya during spring season. They were cut into small pieces and dried at room temperature $\left(25^{\circ} \mathrm{C} \pm 2^{\circ} \mathrm{C}\right)$ for 3 days. The air-dried plant $(1000 \mathrm{~g})$ was extracted with ethanol by Soxhlet extractor. Extracts were concentrated by Rotary evaporation and dry at $45^{\circ} \mathrm{C}$ under reduced pressure for 15-30 min following solvent preparation of extracts and finally the plant with the maceration of water for $24 \mathrm{~h}$ and then the extract was freeze dried. 


\subsubsection{Qualitative phytochemical screening:}

Detection of presence of phytoconstituent in plant extract was as described by Ciulei, (1994), Sofowora, (1993), Umesh et al., (2010) and Harborne, (1998).

\subsubsection{In vitro experiment:}

A laboratory study was performed to examine the sensitivity of $F$. solani, F. moniliforme, F. semitectum and $M$. phaseolina to the plant extracts namely, Retama raetam (flowers, Stems and fruits), Phoenix dactylifera (seeds) and Chrysanthemum trifurcatum (mixer of leaves, stems and roots).

\subsubsection{Fungal inhibition diameter method (FID):}

The multipoint-inoculation technique with needles such as curved sharp pointed (Poppe, 1991) was used to inoculate Petri dishes with the tested fungi (Fig. 1). Drenched plant extract paper-disks at three concentrations, i.e $(5 \%, 10 \%$ and $15 \%)$ in sterile distilled water, were placed on the inoculated PDA medium plate. Paper-disks soaked in sterile water were used as a control. Four replicates were used for each treatment. The fungal-inhibition-diameters (FID) were measured periodically as the growth of each fungus in control treatment reached to the dish edge (Amer, 1995).

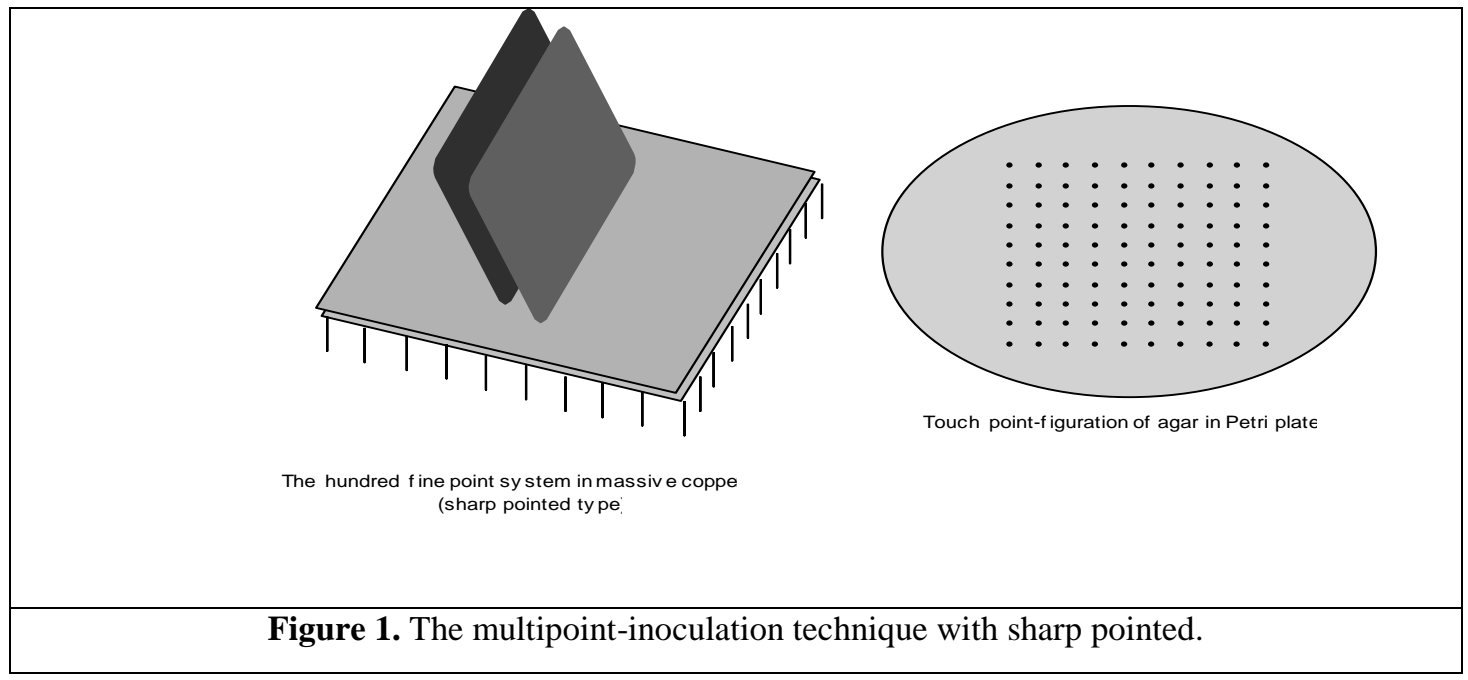

\section{Plant Extracts:}

\section{Experiment Results}

This part planned to evaluate efficacy of some plant extracts in controlling diseases caused by the five tested seed-borne pathogens in vitro.

\subsection{Preliminary Phytochemical screening:}

The screening of these different plant species namely, Retama raetam, Chrysanthemum trifurcatum and Phoenix dactylifera for phytochemical constituets was performed using generally accepted laboratory technique for qualitative determinations. From Table (10), The study indicates the presence of Alkaloids, Flavonoids, Phenolic compounds, Carbohydrates, Glycosides, Acetate, Steroides, Saponins, Tanins and Terpenoids in all the ethanolic extract of the $R$. raetam (fruits, flowers and Stems), C. trifurcatum (mixed of leaves, stems and roots) and $P$. dactylifera (seeds). Alkaloids and carbohydrates were found in all plant extracts, while flavonoids was absent in all plant extracts except $C$. trifurcatum, phenolic compounds were found in all parts of $R$. raetam. Glycosides and acetate were found in fruits and Stems of $R$. raetam but not found in flowers, while steroides was found only in the P. dactylifera and tannin was found only in C. trifurcatum. 
Table 1. Phytochemical screening of the plant extracts.

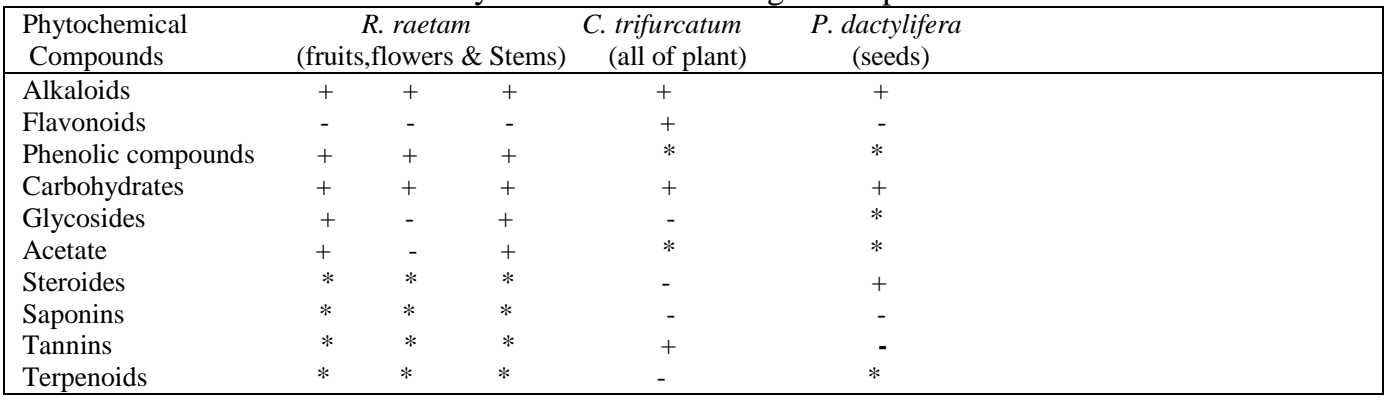

$+=$ Present $; \quad$ - = Absent; $*$ Not tested.

\subsection{In vitro trials:}

\subsubsection{Fungal inhibition diameters (FID) technique:}

Laboratory tests were carried out to check the effect of the tested plant extracts, i.e. $R$. raetam (fruits, flowers and leafs), C. trifurcatum (all of plant) and P. dactylifera (seeds) with different concentrations ( $5 \%$, $10 \%$ and $15 \%$ ) on growth and development of tested pathogens, i.e. F. solani, F. moniliforme, F. semitectum, $S$. sclerotiorum and $M$. phaseolina. Determination of plant extracts efficacy was carried out using fungal inhibition diameter (FID) methods. The obtained results were statistically analyzed, then illustrated in (Table 2 and Fig. 2). All concentrations application rates of the tested plant extracts were, generally, significantly effective in increasing inhibition zone diameters (IZD) of the tested pathogens, where IZD values ranged $14 \mathrm{~mm}$ to $37 \mathrm{~mm}$. Moreover, concentration $15 \%$ was more effective in inhibition of the tested pathogens than other concentrations (Table 2).

All the plant extracts tested showed antifungal activity, results obtained in the present study show that plants extract possesses potential antifungal activity against the tested seed-borne pathogens; however, concentration $15 \%$ and concentration $10 \%$ were found to be more effective antifungal agents than the concentration $5 \%$.

Table 2. Inhibition percent of mycelia growth of some seed-borne pathogens by different concentrations of some plant extracts.

\begin{tabular}{|c|c|c|c|c|c|c|c|c|c|c|}
\hline \multirow{5}{*}{ Pathogens } & \multicolumn{10}{|c|}{ Inhibition zone (mm) } \\
\hline & \multirow{4}{*}{ Control } & \multicolumn{9}{|c|}{ Plant Extracts } \\
\hline & & \multicolumn{3}{|c|}{ R. raetam } & \multicolumn{3}{|c|}{ P. dactylifera } & \multicolumn{3}{|c|}{ C. trifurcatum } \\
\hline & & \multicolumn{9}{|c|}{ Concentration (\%) } \\
\hline & & 5 & 10 & 15 & 5 & 10 & 15 & 5 & 10 & 15 \\
\hline F. solani & 0.0 & 30 & 35 & 37 & 29 & 30 & 32 & 22 & 24 & 28 \\
\hline F. moniliforme & 0.0 & 31 & 33 & 36 & 27 & 28 & 30 & 14 & 17 & 26 \\
\hline F. semitictum & 0.0 & 31 & 34 & 36 & 28 & 29 & 31 & 24 & 26 & 28 \\
\hline S.sclerotiorum & 0.0 & 31 & 32 & 34 & 28 & 29 & 31 & 25 & 27 & 28 \\
\hline M. phaseolina & 0.0 & 27 & 30 & 31 & 24 & 26 & 27 & 15 & 22 & 26 \\
\hline Mean & 0.0 & 30 & 32.8 & 34.8 & 27.2 & 28.4 & 30.2 & 20 & 23.2 & 27.2 \\
\hline
\end{tabular}

L.S.D. at $5 \% 1.23$

Significant inhibition zones were induced in each of the tested pathogens by the tested plant extracts at all concentrations. However, the highest value of IZD was detected in $F$. solani, followed by $F$. moniliforme and F. semitictum ( $37 \mathrm{~mm}, 36 \mathrm{~mm}$ and $36 \mathrm{~mm}$, respectively). Each of the tested plant extracts induced significant IZD values in all the tested pathogens, compared with control. The highest IZD values were detected in $R$. raetam. ie., $15 \%$ to $F$. solani, $F$. moniliforme and $F$. semitictum, $10 \%$ to $F$. solani and $15 \%$ to $S$. sclerotiorum ( $37 \mathrm{~mm}, 36 \mathrm{~mm}, 36 \mathrm{~mm}, 35 \mathrm{~mm}$ and $34 \mathrm{~mm}$, respectively). The lowest values $(5 \%)$ were recorded in $C$. trifurcatum to F. moniliforme and $C$. trifurcatum to M. phaseolina (Fig.2).

Generally, $R$. raetam extracts were most effective, then $P$. dactylifera, followed by $C$. trifurcatum. However, $F$. solani was more sensitive than all tested pathogens, followed by S. sclerotiorum, while, M. phaseolina was low sensitive. 


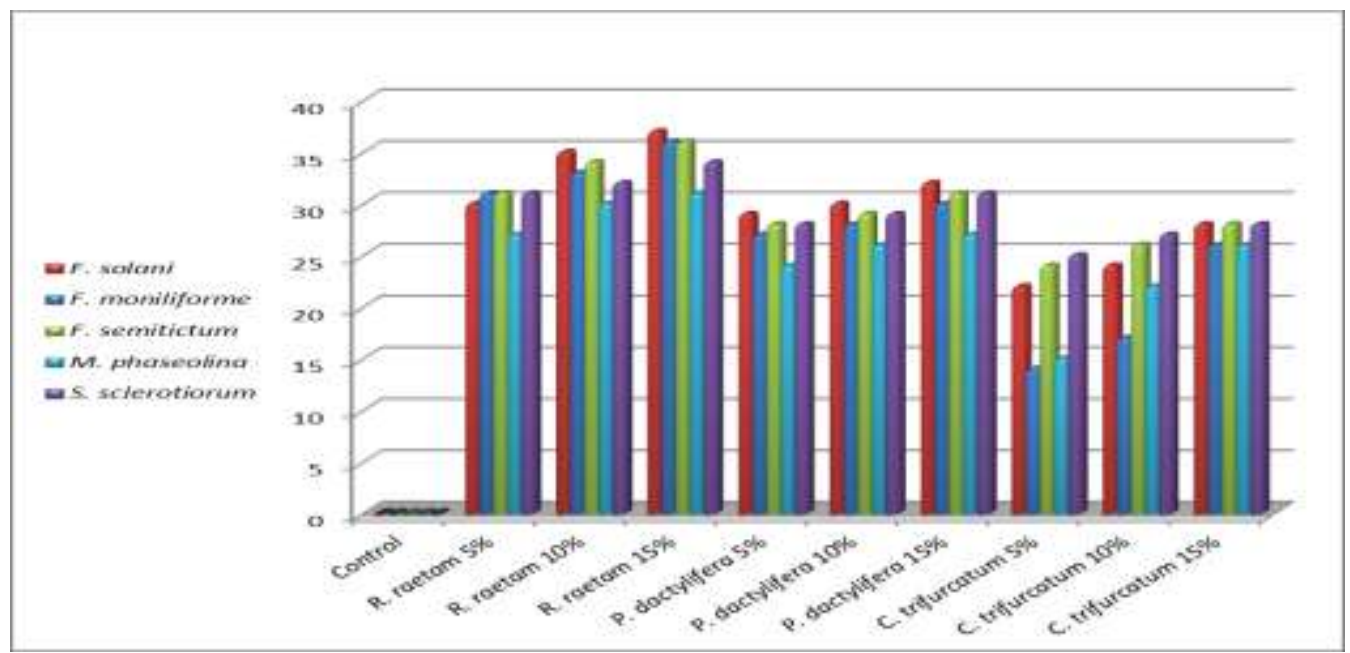

Fig.2. Inhibition percent of mycelia growth of some seed-borne pathogens by different concentrations of some plant extracts.

\section{Discussion}

\section{Plant extracts:}

\subsection{Phytochemical analysis:}

In the present study, ethanol extracts of some medicinal plants: Retama raetam (stems, flowers and fruits), P. dactylifera (seeds) and Chrysanthemum trifurcatum (mixer of leaves, stems and roots). The study indicates the presence of Alkaloids and carbohydrates in the all tested ethanol extracts. Phenolic compounds were found only in all parts of $R$. raetam. Glycosides and acetate were found in the stems and fruits but absent in the flowers of $R$. raetam. Flavonoids were absent in all parts of $R$. raetam. These findings were similar to those reported by El-Shazly et al. (1996) and Abdel Halim et al., (1997). Mobin et al. (2015) reported that, the phytochemical screening of the Retama raetam extracts revealed the presence of alkaloids, phenols, flavonoids, terpenoids, tannins and carbohydrates. However, saponins were absent.

Phytochemical analysis revealed the presence of alkaloids, steroides and carbohydrates in seed ethanol extracts of $P$. dactylifera but none contains flavonoids, saponin and tannins. These results were confirm by Aldaihan and Bhat (2012) and Mallhi et al., (2014). They showed that, phytochemical analysis of leaf, fruit, seed and bark of Phoenix dactylifera revealed the presence of carbohydrates and alkaloids in all parts, and flavonoids, steroids, saponins and tannins were present in some parts. The phenolic profile of the plant revealed presence of mainly cinnamic acids, flavonoid glycosides, flavanols, four free phenolic acids and nine bound phenolic acids (Eong et al., 2006 and Biglari et al., 2008). Fresh dates contain Anthocyanins (Vembu et al., 2012).

\subsection{Antifungal activity:}

In the present study, ethanol extracts of different plant species namely $R$. raetam, $P$. dactylifera and $C$. trifurcatum inhibited the growth of some cucurbits seed-borne pathogens ( $F$. solani, F. moniliforme, $F$. semitectum, S. sclerotiorum and M. phaseolina). All the plant extracts tested showed antifungal activity, results obtained in the present study show that plants extract possesses potential antifungal activity against the tested seed-borne pathogens; however, concentrations $15 \%$ and $10 \%$ were found to be more effective antifungal agents than the concentration 5\%. Alkaloids and carbohydrates were found in all plant extracts, while flavonoids was absent in all plant extracts except $C$. trifurcatum, phenolic compounds were found in all parts of $R$. raetam. Glycosides and acetate were found in fruits and Stems of $R$. raetam but not found in flowers, while steroides was found only in the $P$. dactylifera, tannin was found only in $C$. trifurcatum. The importance of alkaloids, saponins and tannins in various antibiotics used in treating common pathogenic strains has recently been reported by Kubmarawa et al., 2007 and Mensah et al., 2008.

In case of Phoenix dactylifera seeds, ethanolic extract contains saponin, terpenoids, phenolic compounds and glycosides. Ethanolic extract of carica papaya seeds contains saponins, tannins, flavonoids, alkaloids, carbohydrates, phenolic compounds and carotenoids. Flavonoids are known to be synthesized by plants in response to microbial attack. Hence, it should not be surprising that they have been found to be effective antimicrobial substances against a wide array of microorganisms, when tested in-vitro (Delphin et al, 2014). Their activity was probably due to their ability to react with extracellular and soluble proteins and to complex with bacterial cell walls leading to the death of the bacteria (Cowan, 2002). Tannins are also reported to have various physiological effects like antimicrobial. Earlier, it has been reported that methanol and acetone 
extracts of the $P$. dactylifera pits moderately inhibited the growth of gram positive and gram negative bacteria (Sabah et al., 2007; Ammar et al., 2009). However reports on antifungal activity of $P$. dactylifera are unavailable. Different concentrations of Spilanthes acmella showed high inhibition zones in F. oxysporum and F. moniliformis followed by Aspergillus niger and A. paraciticus (Sabitha and Suryanarayana, 2006). Jabeen et al. (2008) found that seed extracts of Moringa oleifera inhibited the growth of $F$. solani and Rhizoctonia solani. Earlier various studies reported that plant extracts had a good potential to control various fungal diseases (AbdEl-Khair and Wafaa, 2007; Joseph et al., 2008; Yasmin et al., 2008; Mdee et al., 2009; Yanar et al., 2011; Salim, 2011).

The phytochemicals derived from root, stem, leaves, fruits, flowers and seeds of medicinal plants include phenolic compounds, essential oils, proteins and antioxidants, and together they work as biocontrol agents (Cragg et al., 1996). The inhibition potential of plant extracts against the growth of microbes was attributed to the presence of antioxidants (Cutter, 2000; Puupponen et al., 2001). It has been reported that the whole date plant (including pits and leaves) contains carbohydrates, alkaloids, steroids, flavonoids, vitamins and tannins. The phenolic profile of the plant revealed presence of mainly cinnamic acids, flavonoid glycosides, flavanols, four free phenolic acids and nine bound phenolic acids (Eong et al., 2006 and Biglari et al., 2008). The results of our study demonstrated positive antifungal activity by date palm extracts against tested pathogenic fungi, which might be due to the selective or synergistic action of various chemicals present in date palm. There were some differences in the antifungal activities of extracts which may be due to differences in phytochemicals found in two varieties of $P$. dactylifera. Previous pharmacological studies on the plant have revealed its various medicinal properties: antibacterial, antifungal, antihypertensive, antioxidant, antiviral, diuretic, hypoglycaemic, hepatoprotective, nephroprotective and cytotoxic effects (Maghrani et al., 2005 and Edziri et al., 2012). Hayet et al., (2007) found that the best activity of $R$. raetam against Gram positive bacteria but low activity against the different Candida spp., i.e. C. glabrata, C. albicans, C. parapsilosis and C. kreusei. On the other hand Edziri et al., (2012) indicated that $R$. raetam was active against Pseudomonas aeruginosa and Escherichia coli and showed important antifungal activity. Strong antifungal activity against Candida species as Ben Sassi et al., (2008) reported that, all extracts of Chrysanthemum plants showed some degree of activity against one or more of the bacterial and yeasts strains.

C. parapsilosis was found to be the most sensitive yeast. The activity against both the types of bacteria may be indicative of the presence of broad spectrum antibiotic compounds or simply general metabolic toxins (Srinivasan et al., 2001). The most active Chrysanthemum extracts tested against bacterial and yeasts strains, contained tannins. However, some anti-infective actions have been assigned to tannins (Haslam, 1996). They can be toxic to bacteria, yeasts and filamentous fungi (Scalbert, 1991). Their mode of antimicrobial action may be related to their ability to inactivate microbial adhesions, enzymes, cell envelope transport proteins and they also complex with polysaccharide (Ya et al., 1988). Other extracts were active against bacteria and contained flavonoids, like methanolic extracts of C. paludosum, C. grandiflorum, $C$. trifurcatum leaves and flowers and $C$. trifurcatum leaves and stems. In fact, flavonoids were known to be synthesized by plants in response to microbial infection (Dixon et al., 1983). It should not be surprising that they have been found in vitro to be effective antimicrobial substances against a wide array of microorganisms. Their activity was probably due to their ability to complex with extracellular and soluble proteins and to complex with bacterial cell walls (Tsuchiya et al., 1996). Methanolic extracts of C. Myconis, C. trifurcatum leaves and flowers and C. trifurcatum leaves and stems have antimicrobial activities and contained tannins, flavonoids and moreover alkaloids which are known to have antimicrobial activity (Omulokoli et al., 1997). Previous studies reported that the other Chrysanthemum species such C. indicum, contained a phenolic compounds, terpenoids, flavonoids (Cheng et al., 2005), oxygenated monoterpens and sesquiterpenes which had antimicrobial activity against a large number of bacterial strains (Shunying et al., 2005).

\section{Conclusion}

Retama raetam extracts have high antifungal activity. Fungus like $F$. solani, $F$. semitictum and $F$. moniliforme were more sensitive with the highest inhibitory zone values for the $R$. raetam plant extract treatments. Further studies are necessary to confirm the present results.

\section{References}

[1]. Abdel Halim OB, Abdel Fattah H and Halim AF (1997) Comparative chemical and biological studies of the alkaloidal content of Lygos species and varieties growing in Egypt, Acta Pharm. Hung., 67: 241-247.

[2]. Abd-El-Khair H and Wafaa MH (2007) Application of some Egyptian medicinal plant extracts against potato late and early blights. Res. J. Agri. Biol. Sci., 3: 166-175.

[3]. Abdu SB (2011). The protective role of Ajwa date against the hepatotoxicity induced by Ochratoxin A. Egyp J Nat Tox; 8: 1-15.

[4]. Ahlem BS, Fethia HS, Imed C, Nathalie B, Mohamed H and Mahjoub A (2008) Chemical composition and antimicrobial activities of the essential oil of (Tunisian) Chrysanthemum trifurcatum (Desf.) Batt. and Trab. flowerheads. C. R. Chim., 11: 324 330 . 
[5]. Ahlem BS, Nathalie B, Mohamed H and Mahjoub A (2014) Essential Oils and Crude Extracts from Chrysanthemum trifurcatum Leaves, Stems and Roots: Chemical Composition and Antibacterial Activity. Journal of Oleo science, 63(6): 607-617.

[6]. Algandaby MM Alghamdi HA, Ashour OM, Abdel-Naim AB, Ghareib SA, Abdel-Sattar EA and Hajar AS (2010) Mechanisms of the antihyperglycemic activity of Retama raetam in streptozotocin-induced diabetic rats. Food and Chemical Toxicology, 48: 2448-2453.

[7]. Amer MA (1995) Evaluation of adjuvants to enhance fungicide efficacy against plant pathogens. Ph.D. Thesis, Faculty of Agricultural and Applied Biological Sciences, Univerrsity of Gent, 200 pp.

[8]. Amin AR, Rashid MM and Meah MB (2009) Efficacy of garlic tablet to control seed-borne fungal pathogens of cucumber. Journal of Agriculture \& Rural Development, 7(1): 135-138.

[9]. Ammar NM, Abou El-Kassem LT, El-Sayed NH, Calabria LM and Tom JM (2009) Flavonoid constituents and antimicrobial activity of date (Phoenix dactylifera L.) seeds growing in Egypt. In: Proceedings of 4th conference on research and development of pharmaceutical industries (Current Challenges). Med. Arom. Plant Sci. Biotechnol., (3):1-5.

[10]. Auzi AA, Gray AI, Salem MM, Badwan AA and Sarker SD (2008) Feruhermonins A-C: Three daucane esters from the seeds of Ferula hermonis (Apiaceae). J Asian Nat Prod Res., 10: 701-707.

[11]. Bahraminejad S, Amiri R, Ghasemi S and Fathi N (2013) Inhibitory effect of some Iranian plant species against three plant pathogenic fungi. Intl J Agri Crop Sci.,5(9):1002-1008.

[12]. Belabid L, Simoussa L and Bayaa B (2010) Effect of some plant extracts on the population of Fusarium oxysporum f. sp. lentis, the causal organism of lentil wilt. Advances Environmental Biology, 4(1): 95-100.

[13]. Ben Sassi A, Skhiri, FH, Bourgougnon N and Aouni M (2008) Antimicrobial activities of four Tunisian Chrysanthemum species. Indian J Med Res., 127: 183-192.

[14]. Bokhari NA and Perveen K (2012) In vitro inhibition potential of Phoenix dactylifera L. extracts on the growth of pathogenic fungi. Journal of Medicinal Plants Research, 6(6): 1083-1088.

[15]. Boulenouar N, Abderrazak M and Abdelkrim C (2011) Antifungal activity and phytochemical screening of extracts from Phoenix dactylifera L. cultivars. Nat Prod Res., 25(20): 1999-2002.

[16]. Cheng W, Li J, You T and Hu C (2005) Anti-inflammatory and immunodulatory activities of the extracts from the inflorescence of Chrysanthemum indicum Linné. J Ethnopharmacol., 101: 334-337.

[17]. Cheriti A, Belboukhari N and Hacini S (2004) Ethnopharmacological survey and phytochemicaln screening of some medicinal plants of Algerian Sahara. Pharm.Res.3(2): 51.

[18]. Chinelo AO, Temilola AF, Abubakar TM, Jamal KM and Habibu AS (2012) Comparative chemical constituents of some desert fruits in Northern Nigeria. Arch. Appl. Sci. Res., 4 (2): 1061-1064.

[19]. Ciulei I (1994) Methodology of analysis of vegetable drug. Romania: United Nations Industrial Development Organisation.

[20]. Cowan MM (2002) Plant products as antimicrobial agents. Clin. Microbiol., (12): 564-582.

[21]. Cragg GM, Simon JE, Jato JG and Sander KM (1996) Drug discovery and development at the National Cancer Institute: Potential for new pharmaceutical crops. Progress in new crops, ASHS Press, Arlington, pp. 554-560.

[22]. Cutter CV (2000) Antimicrobial effect of herb extracts against Escherichia coli, Listeria monocytogenes and Salmonella typhimurium associated with beef. J. Food Prot., 63: 601-607.

[23]. Delphin DV, Haripriya R, Subi S, Jothi D and Thirumalai Vasan P (2014) Phytochemical screening of various ethanolic seed extracts. World Journal of Pharmacy and Pharmaceutical Sciences, 3(7): 1041-1048.

[24]. Dixon RA, Dey PM and Lamb CJ (1983) Phytoalexins: enzymology and molecular biology. Adv Enzymol., 55 : 1-69.

[25]. Djeddi S, Karioti A, Yannakopoulou E, Papadopoulos K, Chatter R and Skaltsa H (2013) Analgesic and Antioxidant Activities of Algerian Retama raetam (Forssk.) Webb \& Berthel Extracts. Rec. Nat. Prod., 7(3): 169-176.

[26]. Dr. Duke's Phytochemical and Ethnobotanical Databases (2011) URL: http://www.ars-grin.gov/cgi-bin/duke/ethnobot.pl.

[27]. Edziri H, Mastouri M, Cheraif I and Aouni M (2010) Chemical composition and antibacterial, antifungal and antioxidant activities of the flower oil of Retama raetam (Forssk.) Webb from Tunisia. Natural Products Research, 24: 789-96.

[28]. Edziri H, Mastouri M, Mahjoub MA, Mighri Z, Mahjoub A and Verschaeve L (2012) Antibacterial, antifungal and cytotoxic activities of two flavonoids from Retama raetam flowers. Molecules., 17: 7284-7293.

[29]. Elouzi AA, Auzi AA,; El-Hammad M and Gray AI (2008) Cytotoxicity study of Ferula hermonis Boiss., Bulletin of Pharmaceutical Sciences, 31: 313-317.

[30]. El-Shazly A, Ateya AM, Witte L and Wink M (1996) Quinolizidine Alkaloid Profiles of Retama raetam, R. sphaerocarpa and R. monosperma. Z. Naturforsch. 51c, 3 (24): 301-308.

[31]. Eong YJ, Hong FA, Tomas B, Adel A, Kader S and Alyson E (2006) The flavonoid glycosides and procyanidin composition of Deglet Noor dates (Phoenix dactylifera). J. Agric. Food Chem., 54: 2405-2411.

[32]. Geroushi A, Auzi AA, Elhwuegi AS, Elzawamm F, El-Sherif E, Nahar L and Sarker SD (2010) Antinociceptive and antiinflammatory activity of Ferula hermonis root oil in experimental animals. Latin American Journal of Pharmacy, 29: 1436-1439.

[33]. GRIN Database (2011) USDA, ARS, National Genetic Resources Program. Germplasm Resources Information Network - (GRIN) [Online Database]. National Germplasm Resources Laboratory, Beltsville, Maryland. URL: http:// www.ars-grin.gov/cgibin/npgs/html/taxon.pl?30932.

[34]. Harborne JB (1969) Chemosystematics of the Leguminosae. Flavonoid and isoflavonoid patterns in the tribe of Genisteae, Phytochemistry, 8: 1449-1456.

[35]. Harborne JB, Boulter D and Tuner BL (1971) Chemotaxonomu of the Leguminosae, Academic Press, London.

[36]. Haslam E (1996) Natural polyphenols (vegetable tanins) as drugs: possible modes of action. J Nat Prod., 59: 205-215.

[37]. Hayet E, Maha M, Samia A, Mata M, Gros P, Raida H, Ali MM, Mohamed AS, Gutmann L, Mighri Z and Mahjoub A (2008) Antimicrobial, antioxidant, and antiviral activities of Retama raetam (Forssk.) Webb flowers growing in Tunisia. World Journal of Microbiology and Biotechnology, 24: 2933-2940.

[38]. Hayet E, Samia A, Patrick G, Ali MM, Maha M, Laurent G, Mighri Z and Mahjoub A (2007) Antimicrobial and Cytotoxic Activity of Marrubium alysson and Retama raetam Grown in Tunisia. Pakistan Journal of Biological Sciences, 10(10): 1759-1762.

[39]. Jabeen R, Shahid M, Jamil A and Ashraf M (2008) Microscopic evaluation of the antimicrobial activity of seed extracts of Moringa oleifera. Pak. J. Bot., 40: 1349-1358.

[40]. Joseph B, Dar MA and Kumar V (2008) Bioefficacy of plant extracts to control Fusarium solani f. sp. Melongenae incitant of brinjal wilt. Global J. Biotech. Biochem., 3: 56-59.

[41]. Kassem M, Mosharrafa SA and Saleh NAM (2000) Tow new flavonoids from Retama raetam. Fitoterapia, 71: 649-654

[42]. Koriem KMM, Farraqm ARH, Badawy AA and El-Toumy SA (2009) Role of some Egyptian medicinal plants against liver and kidney toxicity induced by cadmium chloride. Toxicological Mechanisms and Methods, 19: 524-534. 
[43]. Kubmarawa D, Ajoku GA, Enworem NM and Okorie DA (2007) Preliminary phytochemical and antimicrobial screening of 50 medicinal plants from Nigeria. African Journal of Biotechnology, 6(14): 1690-1696.

[44]. Lin LZ and Harnyl JM (2010) Identification of the phenolic components of Chrysanthemum flower (Chrysanthemum morifolium Ramat). Food Chem., 120: 319-326.

[45]. Mallhi TH, Qadir MI, Ali M, Ahmad B, Khan YH and Atta-Ur-Rehman (2014) Ajwa Date (Phoenix dactylifera): An Emerging Plant in Pharmacological Research. Pak. J. Pharm. Sci., 27(3): 607-616.

[46]. Mdee LK, Masoko P and Eloff JN (2009) The activity of extracts of seven common invasive plant species on fungal phytopathogens. S. Afr. J. Bot., 20: 1010-1016.

[47]. Mehrotra RS (1993) General accounts of fungi. In: Plant Pathology. Tata McGraw Hill Publ. Co., New Delhi, 358 P

[48]. Mensah JK, Okoli RI, Ohaju-Obodo JO and Eifediyi K (2008) Phytochemical, nutritional and medical properties of some leafy vegetables consumed by Edo people of Nigeria. Afr J Biotechnol., 7(14): 2304-2309.

[49]. Mobin M, Khan MN and Abbas ZK (2015) Ecotype Difference in Bioactive Constituents and In vitro Antioxidant Activities of Some Saudi Medicinal Plants. European Journal of Medicinal Plants, 7(3): 125-136.

[50]. Moubasher H (1998) Isoflavonoids from Retama raetam subspecies raetam, isolation, structure elucidationand their antifungal properties. Union Arab. Biol.Cairo., 6: 521-528.

[51]. Omulokoli, E.; Khan, B. and Chhabra, S.C. (1997). Antiplasmodial activity of four Kenyan medicinal plants. J Ethnopharmacol., 56: 133-137.

[52]. Paiva PMG, Gomes FS, Napoleão TH, Sá2 A, Correia MTS and Coelho LCBB (2010) Antimicrobial activity of secondary metabolites and lectins from plants. Current research Technology and Education Topics in Applied Microbiology and Microbial Biotechnology. Ed. A. Méndez-Villas, pp.396-406.

[53]. Poppe J (1991) Multipoint inoculation Systems for quick isolation and transmission of plant pathogens. Med. Landbouww. Rijksuniv. Gent., 56(2): 385-390.

[54]. Puupponen PR, Nohynek, L, Meiier C, Kahkonen M, Heinonen M, Hopia A and Oksman CKM (2001) Antimicrobial properties of phenolic compounds from berries. J. Appl. Microbiol., 90: 494-507.

[55]. Sabah A, Jassim A and Mazen AN (2007) In vitro evaluation of the antiviral activity of an extract of Date Palm (Phoenix dactylifera L.) pits on a Pseudomonas Phage. eCAM, pp. 1-6 doi:10.1093/ecam/nem160.

[56]. Sabitha AR and Suryanarayana UC (2006) Antifungal potential of flower head extract of Spilanthes acmella (Linn.) Afr. J. Biomed. Res., 9: 67-69.

[57]. Sahayaraj K, Borgio JF and Raju G (2009) Antifungal activity of three fern extracts on causative agents of groundnut early leaf spot and rust diseases. Journal of Plant Protection, 49(2): 141-144.

[58]. Salim AB (2011) Effect of some plant extracts on fungal and aflatoxin production. Int. J. Acad. Res., 3: 116-120.

[59]. Satish S, Raghavendra MP and Raveesha KA (2010) Management of seed-borne fungal pathogens of sorghum seeds by aqueous extract of Lawsonia inermis L. Journal Biopesticides. 3(1): 237-241.

[60]. Scalbert A (1991) Antimicrobial properties of tannins. Phytochemistry, 30(12):3875-3883

[61]. Shunying Z, Yang Y, Huaidong Y, Yue Y and Guolin Z (2005) Chemical composition and antimicrobial activity of the essential oils of Chrysanthemum indicum. J Ethnopharmacol., 96: 151-158.

[62]. Sofowora A (1993) Medicinal Plants and Traditional Medicinal in Africa. 2nd Ed. Sunshine House, Ibadan, Nigeria: Spectrum Books Ltd; Screening Plants for Bioactive Agents; pp. 134-156.

[63]. Srinivasan D, Nathan S, Suresh T and Lakshmana PP (2001). Antimicrobial activity of certain Indian medicinal plants used in folkloric medicine. J Ethnopharmacol., 74: 217-20.

[64]. Stephan D, Schmitt A, Carvalho SM, Seddon B and Koch E (2005) Evalution of biocontrol preparations and plant extracts for the control of Phytophthora infestans on potato leaves. European J. Plant Pathol., 111: 1-12.

[65]. Tao W, Zaibiao Z, Qiaosheng G and Pengfei M (2013) Variation in major flavonoids glycosides and caffeoylquinic acids during florescence of three Chrysanthemum morifolium, Ramat cv. 'Hangju' genotypes, Biochem. Syst. Ecol., 47: 74-79.

[66]. Tepe B, Daferera D, Sokmen A, Sokmen M and Polissiou M (2005) Antimicrobial and antioxidant activities of the essential oil and various extracts of Salvia tomentosa Miller (Lamiaceae). Food Chemistry. 90: 333-340.

[67]. Tsuchiya H, Sato M, Miyazaki T, Fujiwara S, Tanigaki S and Ohyama M (1996) Comparative study on the antibacterial activity of phytochemical flavanones against methicillin-resistant Staphylococcus aureus. J Ethnopharmacol., 50: 27-34.

[68]. Ukiya M, Akihisa T, Tokuda H, Suzuki, H, Mukainaka T, Ichiishi E, Yasukawa K, Kasahara Y and Nishino H (2002) Constituents of compositae plants III. Anti tumor promoting effects and cytotoxic activity against human cancer cell lines of triterpene diols and triols from edible Chrysanthemum flowers. Cancer Lett., 177: 7-12.

[69]. Umesh BT, Hermalatha S and Anuj M (2010) Pharmacognostic and phytochemical investigation on root of Cadaba farinosa Forsk. Int J Pharm Bio Sci., 1(2): 1-13.

[70]. Valant-Vetschera KM, Wollenweber E, Faure R and Gaydou E (2003) New exudate flavonoids of species from the Chrysanthemum complex (Asteraceae-Anthemideae). Biochem. Syst. Ecol., 31: 545-548.

[71]. Vembu S, Sivanasan D and Prasanna G (2012) Effect of Phoenix dactylifera on high fat diet induced obesity. J.Chem. Pharm. Res., 4(1): 348-352.

[72]. Vyawahare N, Pujari R, Khsirsagar A, Ingawale D, Patil M and Kagathara V (2009) Phoenix dactylifera: An update of its indegenous uses, phytochemistry and pharmacology. Internet J. Pharma., 7: 1

[73]. Xiaoyan P, Guangtao X, Xinmei Z, Ruilin S and Bo H (2011) Inhibition effects of human gastric carcinoma SGC- 7901 cells on Chrysanthemum flavonoids in vivo. Procedia Engineering, 18: 139-144.

[74]. Ya C, Gaffney SH, Lilley TH and Haslam E (1988) Carbohydrate polyphenol complexation. In: Hemingway RW and Karchesy J.J., editors. Chemistryand significance of condensed tannins. Plenum Press, New York, 553.

[75]. Yanar Y, Kadiolu I, Gökçe A, Demirta I, Gören N, Çam H and Whalon M (2011) In vitro antifungal activities of 26 plant extracts on mycelial growth of Phytophthora infestans (Mont.) de Bary. Afr. J. Biotechnol., 10: 2625-2629.

[76]. Yasmin M, Hossain KS and Bash MA (2008) Effects of some angiospermic plant extracts on in vitro vegetative growth of Fusarium moniliforme. Bangladesh J. Bot., 37: 85-88.

[77]. Zhang YL, Xia Y, Tsogt ZQ and Sun SQ (2012) Study on different extracts of Chrysanthemum indicum by Fourier transform infrared pectroscopy. Guang Pu Xue Yu Guang Pu Fen Xi., 32(12): 3225-3228. 